\title{
Potential Analysis of Tourist Pedicab Innovation Through Si-Cakta Application in Jember Regency
}

\author{
Mushthofa Kamal* \\ Language, Communication, and \\ Tourism Departement \\ Politeknik Negeri Jember \\ Jember, Indonesia \\ mushthofa_kamal@polije.ac.id
}

\author{
Vigo Dewangga \\ Language, Communication, and \\ Tourism Departement \\ Politeknik Negeri Jember \\ Jember, Indonesia \\ vigo_dewangga@polije.ac.id
}

\begin{abstract}
Jember is one of the regencies in East Java, Indonesia that has traditional transportation called Becak Wisata or Tourist Pedicab. The existence of a tourist pedicab in Jember is inseparable from the Jember Fashion Carnaval event which began in 2013. Tourist pedicab became the attention of the Jember regency government. However, the government's attention through the congress has not yet touched the aspects of technology utilization in the form of the internet and innovation in urban tourism activities through this traditional transportation, so the enthusiasm of users (tourists and public) is still low. In addition, the development of online transportation has made competition in the transportation sector tighter. The purpose of this study is to analyze the potential for innovation through a basic design of a tourist pedicab application prototype based on an android application system called Si-Cakta. This study uses a qualitative data approach that obtained from observation and SWOT Analysis. Then Continued TOWS analysis that gives four alternative formulation strategies, namely, Opportunities-Strength (SO), WeaknessesOpportunities (WO), Strength-Threats (ST), and WeaknessesThreat (WT). The findings of this study indicate that Si-Cakta prototype application can potentially be designed to facilitate pedicab drivers and tourists in carrying out of urban tourism activities in Jember Regency.
\end{abstract}

Keywords-urban tourism, tourist pedicab, prototype application

\section{INTRODUCTION}

Transportation is an integral part of the tourism [1], because it has important relationship between tourism and transportation: 1) suitability of access and, 2) quality of transportation services including safety, comfort, frequency of departure, and cost and time efficiency [2]. Currently, transportation has become a basic necessity for all levels of society. The transportation function also plays an important role in the tourism industry, especially in terms of ensuring the best accessibility for tourists [3]. Transportation allows tourists to visit more tourist attractions in a tourist destination in a relatively short period of time. Therefore, the reliability of the transportation system services, including the mode of transportation, is important role of tourism development [4]. Becak or Pedicab is a traditional mode of transportation that still exist along with the development of transportation. The distinctive feature of this traditional mode of transportation lies in its operation which still uses human labor, it provided a good measure of job creation and enterprise development, directly as a result of providing a specialized transport service exclusively for passenger movement [5]. Besides that, the character of the design and the accompanying facilities is something unique that deserves to be maintained [6]. Pedicab is classified as one of the traditional modes of transportation that still exists even it become an option transportation after bus or minibus [7].

Based on the type, the pedicab is divided into two types, namely the regular pedicab and the tourist pedicab. The regular pedicab is intended to transport people and goods from one place to another which is relatively close. Meanwhile, the tourist pedicab is intended to transport tourists from a place to a place that has tourist attraction [8]. Pedicabs and tourism are a combination that can support each other in terms of affordability of a tourist attraction in a tourist destination. [6] stated that the tourist pedicab as a traditional mode of transportation provides a strategic role in supporting the city economy which indirectly has an impact on helping the government in increasing local revenue from the income retribution sector and ensuring the sustainability of economic circulation in society. Tourist pedicabs also have relevance to the growth of tourist destinations and other supporting facilities, including accommodation, and restaurants.

One of the areas in East Java Province that has a tourist pedicab is Jember Regency. The existence of a tourist pedicab in Jember is inseparable from the growth in tourist visits, which in the latest data for 2017 reached 2,300,000 tourists [9]. In addition, the tourist pedicab also plays a role in supporting the implementation of the Jember Fashion Carnaval or JFC event which began in 2013 [10]. The function of a tourist pedicab when organizing the JFC event is used as an alternative transportation in the city that can take tourists to get around in the urban area of Jember Regency. Over time, pedicab has become a concern of the government, it was recorded that in 2017 the number of pedicab reached 1,750 units and modifications will be carried out gradually [11]. During the first pedicab congress organized by Jember Government in December 2017, there were 50 units of tourist pedicab that had been modified with the addition of Jember identity attributes such as depicting leading tourist objects, typical Jember batik, tobacco leaves, and the jembertourism.com website written on it. Next, the second pedicab congress held in 2018 discussed the welfare of pedicab drivers in general and the equipment of pedicab drivers [12]. Then in 2019 the pedicab congress held for the third time by the Jember Regency government discussed the 
welfare of pedicab drivers and modification of tourist pedicabs which was attended by 1250 pedicab drivers [13].

Although there has been a lot of attention from the government towards tourist pedicabs through the holding of several becak congresses, it can be concluded that these activities only focus on improving the design and fulfilling the rights of pedicab drivers, it has not been developing on technology.

Several previous research in terms of tourist transportation, such as the research that conducted by [14] have limitation of application features, because it only displays information of public transportation which leads into tourist destinations. While research conducted in [15] it explained that innovation of tourist pedicab is on physical performance of the pedicab to serve the tourists, and the union as the organization of the tourist pedicab that has networking with formal sector such as government agencies and hotel. In this research we try to utilizing the potential of tourist pedicab through creating an innovation called Si-Cakta application which focusing on traditional transportation (pedicab) for travelling needs in Jember regency. Therefore, the goals of this study are to analyze the potential for developing innovation in tourist pedicab by using the SWOT (Strength, Weakness, Opportunity, Threat), and to try to design the SiCakta for android application as a solution to support urban tourism using a tourist pedicab.

\section{METHOD}

This study used a qualitative descriptive approach, through qualitative methods the researchers obtained data that came from literature studies and interview. Through a qualitative method approach, researchers are helped by the data provided through explanation, opinions, and input.

To gain information related to the issue, interviews with several informants have been conducted. The informants are from: 1) Tourism and culture department of Jember Regency, 2) Transportation department of the Jember Regency, and 3) driver of a tourist pedicab that located in 3 sub-districts, namely Kaliwates sub-distric, Patrang sub-distric, and Sumbersari sub-distric.

The next step was referring to [7] by mapping and grouping of several tourist destinations around Jember regency that located near to the center of the city, so the destinations would be picked around the city. In the mapping step, Google Maps was considered to determine the locations and then apply it to the built information system. This information system would help the tourists to pick certain places and to request a pedicab driver.

To analyze data, SWOT analysis is used in order to explain current constraints and future possibilities of tourist pedicab in Jember Regency. SWOT stands for strengths, weaknesses, opportunities, and threats. Then, continued on TOWS analysis that stands for threats, opportunities, weaknesses, and strengths. TOWS is an action tool that identifies the relationships and selecting strategies, it makes more applicable and reality grounded. There are four different combinations are developed: Firstly, SO strategy use the strengths to take advantage of the opportunities. Secondly, ST strategy use strengths to avoid threats. Thirdly, WO strategy to overcome weaknesses by taking advantage of opportunities. Fourthly, WT strategy to minimize weaknesses and threats.
As for making applications in the form of prototypes, according to [16], he explains that the prototype is the basic form or initial model of a system. Reffering to [16] there are five stages in system development using the prototype. Firstly, identifying the most basic user needs. Secondly, building a prototype by identifying the flow of the system structure that is running, designing the flow of the application from start to finish, designing in the Android programming language. Thirdly, using a prototype. Fourthly, revising and improving the prototype. Ffithly, prototype is complete.

\section{RESULT AND DISCUSSION}

Jember is a regency that has 31 sub-districts. However, the scope of a tourist rickshaw in this research covered 3 located in sub-districts, namely Kaliwates sub-distric, Patrang subdistric, and Sumbersari sub-distric.

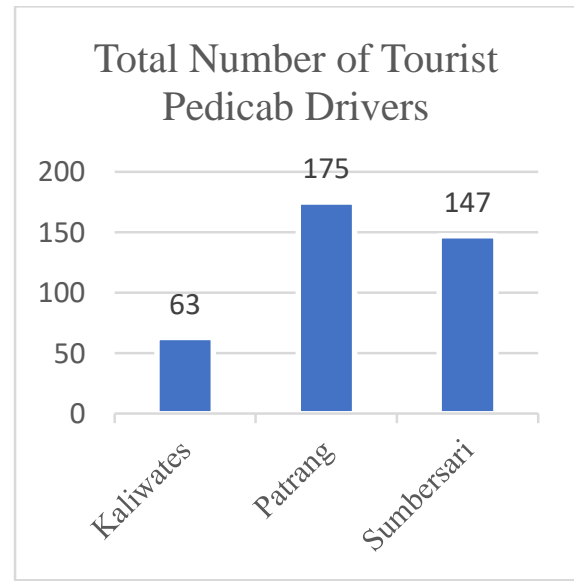

Fig. 1. Number of Tourist Pedicab Drivers

From the data above, it can be concluded that in Kaliwates sub-district there are 63 tourist pedicab drivers, while in Patrang sub-district there are 175 tourist pedicab drivers, and in Sumbersari sub-district there are 147 tourist pedicab drivers. As a whole, there are 385 tourist pedicab drivers who are in the urban area of Jember Regency.

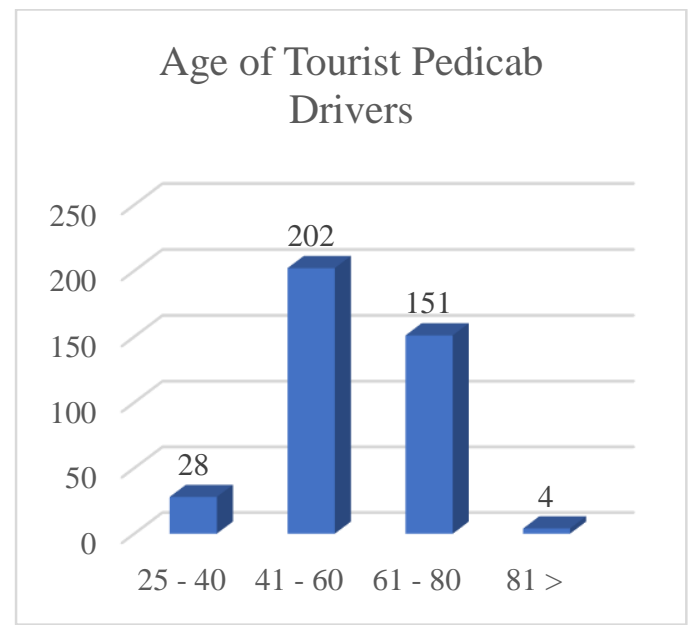

Fig. 2. Age of Tourist Pedicab Drivers

The age of tourist pedicab drivers are currently dominated by men with the age range 41-60 years, which generally they have job experience for more 10-20 years as pedicab drivers. Based on the interview, they are pursuing this job because it 
is difficult to find another job, so the job of a tourist pedicab driver is their main job. An age range of productive age was $25-40$ so they generally work only as a sideline void of time of waiting on idle. A troubled age range was $61-80$ and age 81 above because of his physical health conditions are extremely vulnerable.

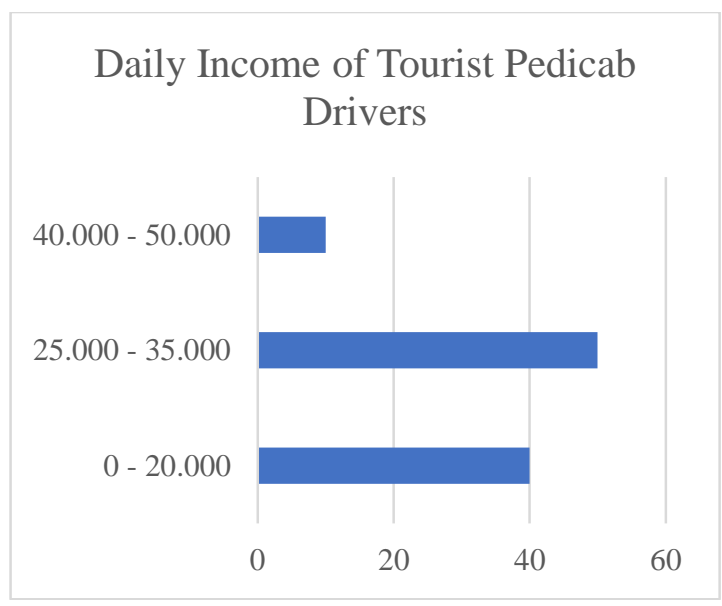

Fig. 3. Daily Income of Tourist Pedicab Drivers

The level of tourist pedicab income is generally low. Based on 100 respondents who answered, the low level their average income at the range of Rp. 0 - Rp. 20,000/days as many as 60 people, sometimes at the moment one day they did not get an income because there were no passengers. Then, at the middle level, 50 people answered that their income about $\mathrm{Rp} 25.000$ - Rp 35.000/days. While the high level, as many as 10 people answered that their income about Rp 40.000 - Rp $50.000 /$ days. Usually they get extra money because of sideline work, such as transporting goods using a becak as a medium of transportation.

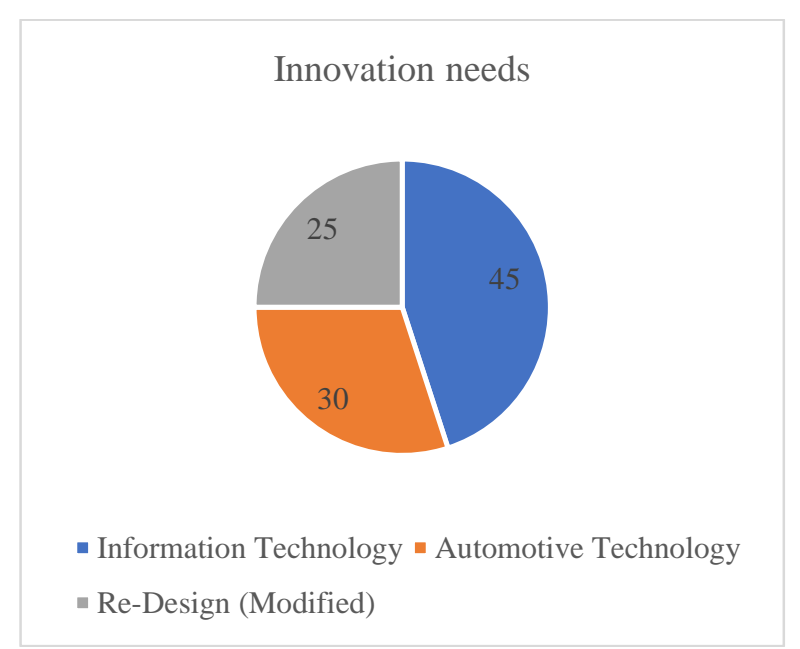

Fig. 4. Opinion of Innovation needs

From the data above, it can be found that majority opinion as many as 45 tourist pedicab drivers generally need innovation of information technology. They think that it is time for technology to make it easier for passengers and drivers. They also feel rivaled by online transportation such as Gojek and Grab, so they need technology such as applications on smartphones to gain more passengers. Another opinion as many as 30 tourist pedicab drivers stated that innovation is needed in the automotive technology so that the power used is mostly through the propulsion engine. While other opinion as many as 25 tourist pedicab drivers stated that innovation is needed in the modified or re-design tourist pedicab, based on current condition, the frame of tourist pedicab considered heavy enough, so light material is needed.

Government of Transportation Department explained that, the congress of tourist pedicab driver has been held three times with the aim of not only re-design the pedicab, but also providing programs assistance to pedicab drivers. The congress was attended by tourist pedicab drivers that came from various sub-districts in Jember regency. They realize that by having a large number of tourist pedicab drivers in Jember Regency, a strategy is needed in their empowerment. It was not only for Jember Fashion Carnival event but also to support tourism activities, especially for urban tourism. Next, according to information from Tourism and Culture Department, the tourist pedicabs initially only to support for JFC event which began in 2013. However, nowadays, tourist pedicab still support tourism activities located in the city center of Jember regency, such as shopping places, museums, mosques, campuses and train stations.

The results of SWOT analysis of tourist pedicab innovation, are as follows:

1) Strength:

a. There are 385 of pedicab drivers spread in urban areas that located in 3 sub-districts (Kaliwates sub-distric, Patrang sub-distric, and Sumbersari sub-distric) .

b. In urban area of Jember regency has some tourist attractions

c. Tourist Pedicab is traditional transportation that is environmentally friendly transport

2) Weakness

a. Pedicab drivers are not technology literate belongs to age range 41-81 above

b. Pedicab drivers who do not have ability to serve the passengers as tourists belongs to age range 61-81 above

c. There is no urban tourism route

3) Opportunity

a. Innovation of Information Technology (IT) is becoming more and more important and this importance will continue to grow and develop in the 21 st century

b. Internet network infrastructure in urban areas is very adequate

c. Jember regency government facilitate pedicab drivers in expanding relation and cooperation with more restaurants and tourist attractions

d. Jember regency government support pedicab drivers to promote all activies related to tourist pedicab

4) Threat

a. Si-Cakta main server accessing become slow because many users will access the main server

b. Si-Cakta user information is still vulnerabilities in data system security 
c. Online motorized transportation get many chance to pick up the passangers rather than tourist pedicab

Based on the results of the SWOT analysis, there are four different combinations are developed:

\section{1) SO strategy}

SO strategy use the strengths to take advantage of the opportunities. The result: Jember regency government should empower the existence of a tourist pedicab through city tour package that has environmentally friendly transport and use online information technology to enables faster and better service that passengers demand.

\section{2) ST strategy}

The ST strategy use strengths to reduce threats. The result : Tourist pedicab drivers should build brand identity that can be recognized by the wider community as environmentally friendly tourism transport. For Si-Cakta main server threat, it should scheduled periodic server maintenance.

\section{3) WO strategy}

The WO strategy to overcome weaknesses by taking advantage of opportunities. The result: Jember regency government should establish relationships with various actors to support tourist pedicab driver, such as tours and travel business, academics, citizens and social entrepreneurs. After that, tourist pedicab driver should get training how to use $\mathrm{Si}$ Cakta application.

\section{4) WT strategy}

The WT strategy to minimize both weaknesses and threats. The results of WT strategy: Jember regency government and tourist pedicab should collaborate to creating innovations in term of attracting visitors, one of which is through utilization of information technology.

Based on the analysis and strategy that has been described, this will be very helpful if there are applications in an effort to increase urban tourism activities by using tourist pedicab services. Therefore, this research try to formulate the potential development of a tourist pedicab through an innovative application called Si-Cakta in the form of a prototype so that it can be used by pedicab drivers and by prospective passengers. However, some limitations should be noted. First, this research only focus to the driver of tourist pedicab. Second, limited area coverage in some Jember sub-disctric that located in 3 sub-districts (Kaliwates sub-distric, Patrang sub-distric, and Sumbersari sub-distric). Third, Inadequate application features design (the location of tourism attractions, cashless payment features, and a friendly user interface).

Si-Cakta is an acronym for Sistem Informasi Becak Wisata (Becak Wisata Information System), which is an application innovation that is presented to empower tourist pedicab drivers while making it easily for visitors to carry out urban tourism activities in Jember Regency. This application is in the form of web and apk. The web version can be accessed by entering the sicakta.com address in the browser, then the APK version can be installed on the smartphone with the following display:

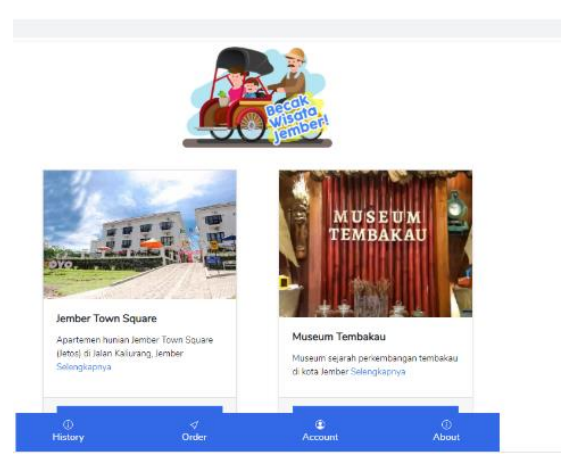

Fig. 5. Display of sicakta.com accessed via a web browser

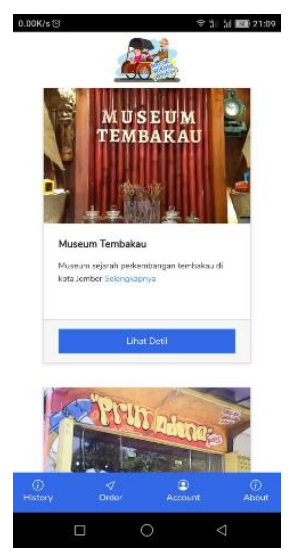

Fig. 6. Display of Si-Cakta APK Version accessed via smartphone

Based on the results of SWOT analysis and strategies that have been described, this application will help to facilitate the needs of tourist pedicab drivers and tourist for traveling activities in the urban area of Jember Regency. The way this application works is almost the same as online transportation applications in general, but the difference of Si Cakta application focuses on empowerment tourist pedicab drivers through tourism activities in urban areas. This prototype application still has many limitations, including the location of tourism attractions, cashless payment features, and a friendly user interface. The further research is still needed in order to develop the prototype.

\section{CONCLUSION}

One area in East Java Province that still has traditional modes of transportation to support tourism activities is Jember regency. In this study, SWOT analysis is used to determine the potential and innovation tourist pedicab. The SWOT analysis facilitated the integration of existing data with primary data obtained in the field and made it possible to identify future development directions. It was demonstrated that SWOT analysis is an effective way of identifying the strengths and weaknesses, and of examining the opportunities and threats, pertaining to potential and innovation analysis. Then continued on TOWS analysis to identifies the relationships and selecting strategies. From the results of the analysis, an innovative idea was designed, namely the SiCakta application prototype that can facilitate pedicab drivers and prospective passengers in traveling in the city area of Jember regency. However support from the Jember district government is still needed to empower tourist pedicab drivers. 


\section{ACKNOWLEDGMENT}

We are grateful to Politeknik Negeri Jember for the financial support to this research, so that it can be completed and submitted to International Conference on Social Science, Humanities and Public Health (ICoSHIP).

\section{REFERENCES}

[1] A. Shah, "The Importance of Transportation to Tourism Development," Acad. J. Econ. Stud., vol. 4, no. 4, pp. 183-187, 2018.

[2] I. B. Santoso, "The Existence of Tourist Pedicab Developing in Malioboro," J. Media Wisata, vol. 16, no. November, pp. 1000-1006, 2018.

[3] M. H. Dewantara, "The Role of Gojek as a Public Access to Tourist in Bali and a Pover of Creative Economics," J. Master Pariwisata, vol. 6, no. 2, pp. 541-556, 2020.

[4] S. P. Warpani, Indira Proboratri \& Warpani, Tourism in regional spatial planning. Bandung: Institut Teknologi Bandung, 2007.

[5] B. Phillips, "Sustainabel Transport - The Pedican Experience," Proc. 30th South. African Transp. Conf., no. July, pp. 445-453, 2011.

[6] A. H. S. Hutama, P. S., \& Negoro, "The Role of Local Government in the Managing of the Probolinggo City Tourist Pedicab," J. Tour. Creat., vol. 3, no. 1, pp. 1-18, 2019.

[7] W. A. W. Sari, C. D. Handayani, Y. R. L. Putri, and R. T. Dewa, "A system to preserve pedicab as cultural heritage in Solo city, Indonesia," AIP Conf. Proc., vol. 1855, no. June, 2017, doi: 10.1063/1.4985504.
[8] P. S. Negoro, Abdul Haris \& Hutama, "Quality of Tourist Pedicab Services for Cruise Ship Tourists in Probolinggo City," J. Penelit. dan Pengemb. Sains dan Hum., vol. 3, no. 2, pp. 77-84, 2019.

[9] Dinas Pariwisata dan Kebudayaan Kabupaten Jember, "Number of Tourist in Jember Regency," lokadata, 2019. [Online]. Available: https://lokadata.beritagar.id/chart/preview/jumlah-kunjunganwisatawan-ke-jember-2009-2017-1551263117.

[10] M. P. Adiati and A. Basalamah, "Socio-Culture Based on Experience and Expectations," Binus Bus. Rev., vol. 5, no. 1, pp. 80-90, 2014.

[11] O. A. Wirawan, "Thousands of pedicabs in Jember regency will be modified," beritajatim.com, 2017. [Online]. Available: http://m.beritajatim.com/politik_pemerintahan/308382/ribuan_becak _di_jember_akan_dimodifikasi.html.

[12] Government of Jember regency, "Government Program for Pedicab Drivers," Pemkab Jember, 2018. [Online]. Available: http://www.jemberkab.go.id/program-pemkab-jember-untuk-tukangbecak/.

[13] A. Mahrus, M, "Holding a Congress, the Regent Fulfills the Rights of Becak Drivers," jatimnews.com, 2019. [Online]. Available: https://www.jatimtimes.com/baca/206746/20191223/184200/gelarkongres-bupati-penuhi-hak-hak-abang-becak.

[14] E. K. Nurwati and N. Rohmah, "Yogyakarta Transportation: Mapping of Mobile-Based Public Transportation Routes as Supporting Media for Tourism Potential," J. Teknol. Inf., vol. XII, no. 35, pp. 1-6, 2017.

[15] M. Damayanti, "Becak Wisata: the Innovation of a Traditional Transportation Mode in Supporting Urban Tourism," J. Planol., vol. 1, no. 21, 2009.

[16] B. Septriani, Evi; Rahmadi, "Pagar Alam City Tourism Application Development," J. Betrik, vol. 17, no. 02, pp. 85-92, 2019. 